DOI: https://doi.org/10.34287/MMT.4(51).2021.2

O. I. Tokarenko, I. O. Andreieva, O. O. Tokarenko, M. M. Surmilo

State Institution «Zaporizhzhia Medical Academy of post-graduate education Ministry of Health of Ukraine» Zaporizhzhia, Ukraine

О. І. Токаренко, І.А. Андреєва,О.О. Токаренко, М. М. Сирлило

Державний заклад «Запорізька медична акаделія післядипломної освіти Міністерства охорони здоров'я України» Запоріжжя, Україна

\title{
EFFECT OF DIET AND EXERCISE-INDUCE WEIGHT LOSS ON LEVEL OF RESISTIN IN PATIENT WITH OBESITY
}

\author{
Вплив дієти і зниэкення маси тіла \\ піА впливом фізичних навантажкень \\ на рівень резистину у пацієнтів 3 ожкиренням
}

Abstract

Purpose of the study. The aims of this study were to determine whether diet and exerciseinduced weight loss reduces level of resistin and whether resistin correlates with changes in body weight.

Matherials and methods. 133 sedentary and overweight/obese people ( 73 men and 60 women) between the ages of 29-57 years were recruited to participate in this study. Each patient underwent a clinical evaluation during the consultation (with measurement of body mass and height), biological tests. All participants refrained from any severe physical activity $48 \mathrm{~h}$ before measurements. All participants were randomized to one of three (exercises or diets) groups and a control group.

Results. Of the 133 patients who completed the study, there were 39 patients in the exercise group (EG), 34 subjects - in the diet group ( $D G)$, 30 - in complex group (DEG) and 30 - in the control group. The diet and exercise intervention employed promoted statistically significant changes in body composition measures compared to controls. Significant changes of resistin were observed in patients from DEG group. Significant changes in glucose homeostasis were registered in patients from $D$-group $(P<0,05)$. Insulin $(P=0,081)$ and resistin $(P=0,145)$ levels tended to interact in $E$ group but no significant differences were observed in them. The univariate regression analysis showed that the changes of resistin were associated with waist-hip ratio and insulin. Regression analysis revealed significant
Peфepam

Мета дослідження. Метою иього дослідження було визначити вплив дієти та фізичного навантаження на рівень резистину $і$ оцінити взаєлозв'язок резистину зі злінали ваги.

Матеріали та методи. До иього дослідження було включено 133 особи із надлірною вагою/ ожирінням (73 чоловіки та 60 жінок) вікол віо 29 до 57 років. Кожен пацієнт проходив клінічну оцінку під час консультації (з вилірол ласи тіла та зростання), біологічні тести. Усі учас ники утрилалися від будь-якої важкої різичной активності за 48 годин до вимірювань та були рандолізовані в одну з трьох груп (фізичне на вантаження та/або дієта) та контрольну групу.

Результати. Зі 133 пацієнтів у групі фізичного навантаження (ФН) було 39 пацієнтів, 34 суб“єктів - у групі diєтотерапї (Д), $30-$ - колn лексній групі (ДФН) та 30 - у контрольній групі. Застосування дієти та фізичних вправ сприяло статистично значилил злінал у масі тіла по рівняно з контролел. Статистично значущі зліни рівня резистину спостерігалися у пацієнтів із групи ДФН. Статистично значущі зліни у рівні глюкози були зареєстровані у пацієнтів із Д-групи $(P<0,05)$. Рівні інсуліну $(P=0,076)$ та резистину ( $P=0,137)$ мали тенденцію до зниження групи ФН, але статистично достовірних відлінностей встановлено не було. Однофакторний регресійний аналіз показав, що зліни резистину були взаєлопов'язані зі співвідношеннял обсяг таліӥ (ОT) та обсяг стегна (OC) та з інсулінол. Регресійний аналіз 
correlations between changes in resistin to insulin ( $r=0,363, R^{2}=0,174, P=0,038$ ) and resistin to waist-hip ratio $\left(r=0,408, R^{2}=0,158, p=0,018\right)$.

Conclusions. Participants in the diet and exercise intervention group experienced significant reductions in body weight and level of resistin. Resistin statistically significant correlates with insulin level but not with HOMA index. Regression analysis revealed significant correlations between changes in resistin to insulin ( $r=0,363, R^{2}=0,174$, $P=0,038)$ and resistin to waist-hip ratio $(r=0,408$, $R^{2}=0,158, p=0,018$ ).

Keywords: Obesity, resistin, diet, exercises, insulin resistance, HOMA. виявив статистично значущі взаєлозв'язки між злінами резистину та інсуліну $(r=0,363$, $\left.R^{2}=0,174, P=0,038\right)$ та співвідношенням OT/OC $\left(r=0,408, R^{2}=0,158, p=0,018\right)$.

Висновки. У пацієнтів із колплексної групи з фізичнил навантаженнял та дієтотерапією делонстрували статистичне значуще зниження маси тіла, рівня резистину та резистентності до інсуліну. Резистин статистично значно корелює з рівнел інсуліну, але не з індексол НОМА. Регресійний аналіз виявив статистично значущі взаєлозв'язки ліж злінали резистину та інсуліну ( $\left.r=0,363, R^{2}=0,174, P=0,038\right)$ та співвідношенняли OT/OC $\left(r=0,408, R^{2}=0,158, p=0,018\right)$.

Ключові слова: Ожиріння, резистин, дієта, фізичне навантаження, інсулінорезистентність, HOMA.

The prevalence of obesity has risen to unacceptable levels in both men and women worldwide with resultant hazardous health implications. Genetic, environmental, and behavioral factors influence the development of obesity [1]. Obesity is associated with and contributes to a shortened life span, type 2 diabetes mellitus, cardiovascular disease, some cancers, kidney disease, obstructive sleep apnea, gout, osteoarthritis, and hepatobiliary disease, among others. Weight loss reduces all of these diseases in a dose-related manner - the more weight lost, the better the outcome [2, 3].

Obesity is associated with a chronic inflammatory response, characterized by abnormal adipokine production, and the activation of some pro-inflammatory signaling pathways, resulting in the alteration of several biological markers of inflammation such as C-reactive protein (CRP), interleukin-6 (IL-6), tumor necrosis factor alpha $(\mathrm{TNF} \alpha)$, adiponectin, leptin and resistin [5, 6]. Resistin, a small secretory molecule, has been implicated to play an important role in the development of insulin resistance under obese condition [4, 7]. Resistin has emerged as novel predictors of cardiovascular diseases and proposed as a link between obesity and type 2 diabetes and may modulate numerous steps in the insulin-signaling pathway $[8,9]$.

A number of studies have shown that diet and exercise are highly effective in promoting weight loss that leads to improve inflammatory markers of obesity and enhanced health and overall fitness. Most research has shown that programs including both diet and exercise produce greater weight loss than diet alone soon after intervention period and after 1 year of follow up in overweight and obese individuals [10]. Previous reports have shown that exercise improves serum leptin and adiponectin abnormalities in overweight and obese individuals; however, results to date are controversial.
The aims of this study were to determine whether diet and exercise-induced weight loss reduces level of resistin in patients with obesity.

\section{MATERIALS AND METHODS}

133 sedentary and overweight/obese people (73 men and 60 women) between the ages of 29-57 years were recruited to participate in this study.

All participants completed a personal and medical/health history document that included description of their occupational and exercise habits and history.

Our present research was approved by the clinical research ethics committee of SI «Zaporizhzhia Medical Academy of Post-Graduate Education Ministry of Health of Ukraine». Written informed consent was obtained from all patients. Research was conducted in accordance with the 1964 Helsinki Declaration.

Candidates were excluded from the study if they presented with: 1) any deconpensated metabolic or cardiovascular disorder, including arterial hypertension, ischemic cardiac disease, arrhythmias, diabetes, thyroid diseases; 2) hepatic, renal, musculoskeletal, autoimmune, neurological disease or impairment of cognitive function; 3) were pregnant, breastfeeding, or had an interest in becoming pregnant during the study; 4) were currently taking prescribed medications or dietary supplements for hyperlipidemia or weight loss supplements within three months before the start of the study; 5) drug and alcohol abuse; 6) rejection of sighing of informed consent signed consent statements.

All participants were randomized to one of three (exercises or diets) groups and a control group. Those who randomized to the control group agreed to serve as a control during the study in which they did not change their normal diet or exercise habits until the study was completed. 
Clinical characteristic of enrolled patients

\begin{tabular}{|l|c|c|c|c|}
\hline \multicolumn{1}{|c|}{ Parameters, units } & $\begin{array}{c}\text { Group D } \\
(\mathbf{n = 3 4 )}\end{array}$ & $\begin{array}{c}\text { Group E } \\
(\mathbf{n}=\mathbf{3 9 )}\end{array}$ & $\begin{array}{c}\text { Group DE } \\
(\mathbf{n = 3 0 )}\end{array}$ & $\begin{array}{c}\text { Control group } \\
(\mathbf{n}=\mathbf{3 0})\end{array}$ \\
\hline Male/Female (n) $(\mathrm{n})$ & $20 / 14$ & $22 / 17$ & $16 / 14$ & $15 / \mathbf{1 5}$ \\
\hline Mean age (years) & $42,4 \pm 4,0$ & $40,1 \pm 3,8$ & $42,8 \pm 4,3$ & $39,7 \pm 3,3$ \\
\hline BMI (kg/m $\left.{ }^{2}\right)$ & $32,5 \pm 2,9$ & $33,4 \pm 3,9$ & $32,7 \pm 2,5$ & $22,4 \pm 3,1$ \\
\hline Duration of obesity, years & $12,7 \pm 4,6$ & $12,3 \pm 4,2$ & $11,8 \pm 3,6$ & 0 \\
\hline
\end{tabular}

Each patient underwent a clinical evaluation during the consultation (with measurement of body mass and height), biological tests. All participants refrained from any severe physical activity $48 \mathrm{~h}$ before measurements.

All subjects were inactive, and none reported engaging in systemic (more than one time per week) sport activities before the study.

Patients in the exercise group underwent a 16-week aerobic exercise training program consisting of four 45-60 min sessions per week (50-85\% maximum oxygen consumption). Aerobic exercise consisted mainly of walking or running on a treadmill, cycling, and calisthenics involving upper and lower limbs. Moreover, subjects in the exercise group were encouraged to increase daily physical activities (brisk walking, etc.). Control subjects were instructed to maintain their habitual activities. The circuit training sessions were supervised by trained fitness instructors who provided feedback about appropriate exercise technique and led self-monitoring of heart rate in order to maintain heart rate between $60-80 \%$ of age-predicted maximal heart rate.

Body mass index (BMI) of the patients was calculated as weight divided by height squared $\left(\mathrm{kg} \cdot \mathrm{m}^{2}\right)$.

Plasma resistin (Antigenix America Inc. (USA), insulin (AO Vector-best, Ukraine), and IL-18 (AO Vector-best, Ukraine) were quantified using commercially available enzyme-linked immunosorbent assay kits. Fasting serum blood glucose was analyzed by «Screen Master Plus» (Hospitex Diagnostic, Switzeland). Insulin resistance was estimated by HOMA-IR. Samples were frozen and stored $\left(-80{ }^{\circ} \mathrm{C}\right)$ until analysis in the same assay.

Participants in the DE group were instructed to follow the prescribed diet plan. The diet consisted of consuming $1,200 \mathrm{kcals} /$ day for one week followed by $1,500 \mathrm{kcals} /$ day for 11 weeks with a prescribed macronutrient content of $45 \%$ protein, $30 \%$ carbohydrate, and $25 \%$ fat in both diet phases. A registered dietitian met with participants prior to the study to explain how to follow the prescribed meal plans and met with them weekly throughout the study to review diet compliance.

Statistical analysis. The quantitative variables were expressed as means \pm SD. Categorical variables were presented as percentages. Comparisons within groups were performed by paired Student's t-test and between groups by Student's independent t-test and Mann-Whitney U-test. Normality of distribution was assessed by Kolmogorov-Smirnov test. Correlations were performed using Pearson's correlation coefficient for univariate analysis and multiple regression analysis for all variables. A $\mathrm{P}$ value of $<0,05$ was considered statistically significant. A P-value $<0,05$ was considered to indicate a statistically significant difference between groups. Calculations were performed with SPSS-software (Version 23.0; SPSS, Chicago, IL).

\section{RESULTS}

All patients have obesity 1 and 2 stages. The prevalence of 2-d stage of obesity was higher in females than males. This difference was statistically significant $(P<0,05)$. The prevalence was increased with the age. It was highest in the age group of 45-49 years. This difference was also statistically significant $(\mathrm{P}<0,05)$. Furthermore, $37,2 \%$ all patients had insulin resistance and increasing level of fasting glucose.

Anthropometric measurements observed at baseline and after 12-weeks of intervention for the all four groups. Significant time and group effects were observed indicating that participants in the DEG group lost more weight, BMI in comparison with DG group and EG group.

Thus, the diet and exercise intervention employed promoted statistically significant changes in body composition measures compared to controls (table 2).

Thus, the diet and exercise intervention employed promoted statistically significant changes in body composition measures compared to controls.

Table 2 also shows impact on markers of glucose homeostasis and related hormones at baseline and 12 weeks after intervention. Significant changes of resistin and HOMA index were observed in patients from DEG group (resistin and HOMA decreased $(-0,417) \mathrm{pg} / \mathrm{ml}$ and $(-0,709)$ respectively). Significant changes in glucose homeostasis were registered in patients from $\mathrm{D}$-group $(\mathrm{P}<0,05)$. Insulin $(\mathrm{P}=0,074)$ and resistin $(\mathrm{P}=0,147)$ levels tended to interact in $\mathrm{E}$ group but no significant 
differences were observed in them.

Statistically significant positive correlations at baseline were detected between the BMI and HOMA index, resistin and insulin $(r=0,281$, $\mathrm{P}=0,011 ; \mathrm{r}=0,453, \mathrm{P}=0,013 ; \mathrm{r}=0,289$, $\mathrm{P}=0,012$; respectively). The waist-hip ratio was positively correlated with insulin $(r=0,507$, $\mathrm{P}=0,008)$, HOMA index $(\mathrm{r}=0,319, \mathrm{P}=0,043)$ and resistin level $(\mathrm{r}=0,314 ; \mathrm{P}=0,027)$. There were no statistically significant correlations between the resistin level at baseline and the HOMA index $(\mathrm{r}=0,108, \mathrm{P}=0,082)$. Resistin also correlate with insulin $(r=0,364, R=0,016)$, and the mean age $(r=0,403, R=0,018)$. Analysis of changes from baseline indicated that resistin significantly correlated with $\mathrm{BMI}$, waist-hip ratio and insulin $(\mathrm{r}=0,332, \mathrm{P}=0,046 ; \mathrm{r}=0,524, \mathrm{P}=0,003$; $\mathrm{r}=0,376, \mathrm{P}=0,007$ respectively). The univariate regression analysis showed that the changes of resistin were associated with waist-hip ratio and insulin. Regression analysis revealed significant correlations between changes in resistin to insulin $\left(\mathrm{r}=0,363, \mathrm{R}^{2}=0,174, \mathrm{P}=0,038\right)$ and resistin to waist-hip ratio $\left(r=0,408, R^{2}=0,158, p=0,018\right)$.

Results of this study revealed that participants in the diet and exercise intervention group experienced significant reductions in body weight, level of resistin and insulin resistance.

Previous studies showed mixed results on the effects of exercise and/or hypocaloric diet on resistin [2, 11, 12, 13]. For example, Reinehr and colleagues studied the change in weight status and resistin level over a 1-year period in obese children participating in an exercise, nutrition education (high carbohydrate, fat reduced diet), and behavior therapy that included individual psychological care of the child and his or her family [14]. They found significant weight change but no significant change in resistin levels. Additionally, there were no significant correlations between changes of resistin and changes of BMI, percentage body fat, waist-to-hip ratio, or insulin resistance index. These findings didn`t support results observed in the present study. However, Alissa E and al. reported that 43 overweight to obese individuals who underwent dietary and physical activity intervention as compared to controls $(n=20)$ observed a mean weight reduction of $-4,5 \mathrm{~kg}$ and significant increase in serum resistin levels [15].

Our study had some limits. We only investigated the impact on a relatively small cohort of women and there may be sex differences in resistin response to a diet and exercise intervention. In addition, it is possible that the normal variability in some assays performed will have influenced results given the low $n$-size studied. Nevertheless, additional research needs to be conducted with larger sample size in men and women adhering to different types of exercise and diet interventions to further assess the impact of weight and fat loss on resistin.

\section{CONCLUSIONS}

Participants in the diet and exercise intervention group experienced significant reductions in body weight, level of resistin and insulin resistance. Resistin statistically significant correlates with insulin level but not with HOMA index. Regression analysis revealed significant correlations between changes in resistin to insulin $\left(r=0,363, R^{2}=0,174\right.$, $\mathrm{P}=0,038)$ and resistin to waist-hip ratio $(\mathrm{r}=0,408$, $\left.\mathrm{R}^{2}=0,158, \mathrm{p}=0,018\right)$.

Table 2

Anthropometric measurements and serum markers in obtained subjects

\begin{tabular}{|c|c|c|c|c|}
\hline Variables & Group & 0 week & 12 week & P-value \\
\hline \multirow{4}{*}{ Weight $(\mathrm{kg})$} & Group 1DG & $88,4 \pm 8,3$ & $81,6 \pm 6,2$ & 0,013 \\
\cline { 2 - 5 } & Group 2EG & $92,6 \pm 8,5$ & $81,4 \pm 7,2$ & 0,017 \\
\cline { 2 - 5 } & Group 3 DEG & $90,2 \pm 8,1$ & $79,3 \pm 7,0$ & 0,009 \\
\cline { 2 - 5 } & Control group & $74,7 \pm 5,8$ & $76,3 \pm 5,4$ & 0,188 \\
\hline \multirow{4}{*}{ BMI $\left(\mathrm{kg} / \mathrm{m}^{2}\right)$} & Group 1DG & $32,5 \pm 2,9$ & $30,1 \pm 2,7$ & 0,058 \\
\cline { 2 - 5 } & Group 2EG & $33,4 \pm 3,9$ & $29,7 \pm 3,3$ & 0,067 \\
\cline { 2 - 5 } & Group 3 DEG & $32,7 \pm 2,5$ & $28,7 \pm 3,2$ & 0,004 \\
\cline { 2 - 5 } & Control group & $22,4 \pm 3,1$ & $23,2 \pm 2,3$ & 0,227 \\
\hline \multirow{3}{*}{$\begin{array}{l}\text { Resistin } \\
\text { ng/ml) }\end{array}$} & Group 1 DG & $2,61[2,16 ; 3,94]$ & $2,28[2,02 ; 3,57]$ & 0,093 \\
\cline { 2 - 5 } & Group 2 EG & $2,69[2,18 ; 3,67]$ & $2,32[2,04 ; 3,67]$ & 0,088 \\
\cline { 2 - 5 } & Group 3 DEG & $2,52[2,01 ; 2,90]$ & $2,11[1,79 ; 2,64]$ & 0,027 \\
\cline { 2 - 5 } & Control group & $2,66[2,09 ; 3,68]$ & $2,11[1,88 ; 3,12]$ & 0,724 \\
\hline
\end{tabular}

\section{REFERENCE}

1. Bray G, Heisel W, Afshin A, Jensen M, Management: An Endocrine Society Scientific Dietz W, Long M et al. The Science of Obesity Statement. Endocrine Reviews. 2018; 39 (2): $79-132$. 14 
2. Deb A, Deshmukh B, Ramteke P, Bhati F, Bhat M. Resistin: A journey from metabolism to cancer. Translational Oncology. 2021; 14 (10): 101178.

3. Park H, Ahima R. Resistin in Rodents and Humans. Diabetes \& Metabolism Journal. 2013; 37 (6): 404.

4. Tripathi D, Kant S, Pandey S, Ehtesham N. Resistin in metabolism, inflammation, and disease. The FEBS Journal. 2020; 287 (15): 3141-3149.

5. Earnest C, Lockard B, Coletta A, Galvan E, Rasmussen $\mathrm{C}$ et al. Efficacy of a randomized trial examining commercial weight loss programs and exercise on metabolic syndrome in overweight and obese women. Applied Physiology, Nutrition, and Metabolism. 2017; 42 (2): 216-227.

6. Acquarone E, Monacelli F, Borghi R, Nencioni A, Odetti P. Resistin: A reappraisal. Mechanisms of Ageing and Development. 2019; 178: 46-63.

7. Khanna D, Baetge C, Simbo S, Lockard B, Galvan E, et al. Effects of Diet and ExerciseInduced Weight Loss in Sedentary Obese Women on Inflammatory Markers, Resistin, and Visfatin. Journal of Nutrition and Obesity. 2017; 1 (1): 102-110.

8. Pandey R. Resistin, Is There any Role in the Mediation of Obesity, Insulin Resistance and TypeII Diabetes Mellitus? Juniper Online Journal of Case Studies. 2018; 6 (3).

9. Park H, Kwak M, Kim H, Ahima R. Linking resistin, inflammation, and cardiometabolic diseases. The Korean Journal of Internal Medicine. 2017; 32 (2): 239-247.

10. Su K, Li Y, Zhang D, Yuan J, Zhang C, Liu Y et al. Relation of Circulating Resistin to Insulin Resistance in Type 2 Diabetes and Obesity: A Systematic Review and Meta-Analysis. Frontiers in Physiology. 2019; 10.

11. Badoer E. Cardiovascular and Metabolic Crosstalk in the Brain: Leptin and Resistin. Frontiers in Physiology. 2021; 12.

12. Giandalia A, Giorgianni L, Lo Piano F, Alibrandi A, Consolo F, Longo Elia G et al. Resistin levels and inflammatory and endothelial dysfunction markers in obese postmenopausal women with type 2 diabetes mellitus. Diabetology \& Metabolic Syndrome. 2021; 13 (1).

13. Abdalla M. Salivary resistin level and its association with insulin resistance in obese individuals. World Journal of Diabetes. 2021; 12 (9): 1507-1517.

14. Reinehr T, Roth C, Menke T, Andler W. Resistin concentrations before and after weight loss in obese children. International Journal of Obesity. 2015; 30 (2): 297-301.

15. Alissa E, Alzughaibi L, Marzouki Z. Association between serum resistin, adiposity measures and inflammatory makers in women without cardiovascular diseases. Chemistry and Physics of Lipids. 2019; 218: 136-140. 